\title{
Orthogonal dual thiol-chloroacetyl and thiol-ene couplings for the sequential one-pot assembly of heteroglycoclusters
}

\author{
Michele Fiore ${ }^{1}$, Gour Chand Daskhan ${ }^{1}$, Baptiste Thomas ${ }^{1}$ \\ and Olivier Renaudet ${ }^{* 1,2}$
}

\author{
Full Research Paper \\ Address: \\ ${ }^{1}$ Département de Chimie Moléculaire, UMR-CNRS 5250 \& ICMG \\ FR2607, Université Joseph Fourier, PB 53, 38041 Grenoble Cedex 9, \\ France and ${ }^{2}$ Institut Universitaire de France, 103 Boulevard \\ Saint-Michel, 75005 Paris, France \\ Email: \\ Olivier Renaudet ${ }^{*}$ - olivier.renaudet@ujf-grenoble.fr \\ * Corresponding author \\ Keywords: \\ chemoselective ligation; heteroglycocluster; multivalency; multivalent \\ glycosystems; one-pot synthesis
}

Open Access

\author{
Beilstein J. Org. Chem. 2014, 10, 1557-1563. \\ doi:10.3762/bjoc. 10.160
}

Received: 03 March 2014

Accepted: 10 June 2014

Published: 08 July 2014

This article is part of the Thematic Series "Multivalent glycosystems for nanoscience".

Guest Editor: B. Turnbull

(C) 2014 Fiore et al; licensee Beilstein-Institut. License and terms: see end of document.

\begin{abstract}
We describe the first one-pot orthogonal strategy to prepare well-defined cyclopeptide-based heteroglycoclusters (hGCs) from glycosyl thiols. Both thiol-chloroactetyl coupling (TCC) and thiol-ene coupling (TEC) have been used to decorate cyclopeptides regioselectively with diverse combination of sugars. We demonstrate that the reaction sequence starting with TCC can be performed one-pot whereas the reverse sequence requires a purification step after the TEC reaction. The versatility of this orthogonal strategy has been demonstrated through the synthesis of diverse hGCs displaying alternating binary combinations of $\alpha$-D-Man or $\beta$-D-GlcNAc, thus providing rapid access to attractive heteroglycosylated platforms for diverse biological applications.
\end{abstract}

\section{Introduction}

Multivalent carbohydrate-protein interactions are complex mechanisms that play key roles in biology [1]. To decipher, exploit or inhibit these recognition processes, a large variety of synthetic multivalent glycoconjugates have been developed over the last decade [2-4]. For a long time, these structures have capitalized on the utilization of a core scaffold decorated with identical sugars which are covalently linked through various spacers. While mimicking the multivalent sugar display of bio- logical systems, these structures poorly reflect their inherent heterogenicity which hampers progresses towards the detailed elucidation of carbohydrate-protein interactions and the discovery of more selective ligands. Heteromultivalent ligands, namely heteroglycoclusters (hGCs), represent ideal structures to achieve this purpose [5]. A few recent reports described the construction of various hGCs based on the successive attachment of sugar residues on a core scaffold such as sugar [6,7], 
peptide [8-10], dendrimer [11,12], cyclodextrin [13-15] and polymer [16]. The most common synthetic strategy to build such hGCs relies on a fragment-coupling approach using thiol-ene coupling [17], copper(I)-catalyzed alkyne-azide cycloaddition (CuAAC) [18] or $\mathrm{S}_{\mathrm{N}} 2$ reaction [19]. In addition, orthogonal chemoselective ligations were proved more attractive strategies to prepare hGCs in high yields, in part because they require less synthetic and purification steps. For example, oxime and CuAAC ligations have been used in our group to prepare tetravalent structures displaying two sugars either in 2:2 or 3:1 relative proportions [20]. In the meanwhile, the group of A. Dondoni has developed a sequential orthogonal TEC in combination with $\mathrm{CuAAC}$ for grafting two different sugar motifs on calix[4]arene scaffold [21].

Herein we report a new strategy based on both thiol-chloroactetyl coupling (TCC) and thiol-ene coupling (TEC) to prepare hGCs from glycosyl thiols and cyclopeptide scaffolds displaying chloroacetyl (ClAc) and allyloxycarbonyl (Alloc) groups and vice versa. We demonstrate that cyclopeptides regioselectively decorated with four sugars on one side, and two other sugars on the other side can be obtained either by a stepwise or a one-pot protocol depending on the reaction sequence (Figure 1). It should be mentioned that during the course of this study, the group of R. Roy has demonstrated the orthogonality of these two reactions for the growth of multifuncional dendrimers [22].

\section{Results and Discussion}

Owing to their straightforward access, their high nucleophilicity and the stability of thioether conjugates, glycosyl thiols [23,24], $\alpha$-D-ManSH 1 and $\beta$-D-GlcNAcSH 2 have been selected for this study (Scheme 1). Such derivatives have proved to be useful in bioconjugates chemistry [25] and for the preparation of thioether-linked tetravalent glycocyclopeptides which have shown highest inhibition against a model lectin in comparison with analogues bearing oxime and triazole linkage
[26]. Glycosyl thiols $\alpha$-D-ManSH 1 and $\beta$-D-GlcNAcSH 2 were prepared from the corresponding bromo peracetyl and chloro peracetyl sugars by treatment with potassium thioacetate followed by de- $O$-acetylation under standard conditions [24].

Cyclopeptide $\mathbf{3}$ displaying two orthogonal functionalities, i.e., four lysine residues functionalized with Alloc groups [27] pointing on the upper face, and two lysine residues protected with chloroacetyl moiety at the lower face has been prepared. To evaluate the importance of the reaction sequences, we first performed the TEC reaction using $\alpha$-D-ManSH 1 . This reaction was carried out in a mixture of DMF and $\mathrm{H}_{2} \mathrm{O}$ under UV irradiation $(\lambda=365 \mathrm{~nm})$ in the presence of 2,2-dimethoxy-2-phenylacetophenone (DPAP) as a radical initiator (Scheme 1, route A). In previous studies [26], we observed that the TEC reaction requires the utilization of 3 equivalents of sugar per reaction site to be complete. Disappearance of starting material was indeed observed by reversed-phase HPLC after 45 minutes. The formation of the desired intermediate $\mathbf{4}$ having two chloroacetyl groups on the other side was confirmed by ESI mass spectrometry (see Supporting Information File 1 and Table 1). As expected, the chloroacetyl groups remained unreactive under these conditions as no partially glycosylated product was observed. Even though the HPLC profile of the crude mixture showed a clean reaction mixture, we were aware that the remaining presence of $\mathbf{1}$ could lead to the formation of an unwanted mixture of products. However we performed the next TCC reaction without further purification. The reaction occurred with a slight excess of $\mathbf{2}$ (1.2 equiv per reactive site) in the presence of $\mathrm{NaH}$ in dry DMF. Expectedly, this route gave a heterogeneous mixture of inseparable products, thus indicating that removal of the unreacted excess of sugar $\mathbf{1}$ is mandatory to avoid its addition during the TCC reaction. After purification, compound 4 was obtained in $46 \%$ yield and subsequently subjected to the TCC reaction with $\beta$-D-GlcNAcSH 2 under conditions described above. Compound 5, wherein $\alpha-\mathrm{D}-\mathrm{Man}$ and $\beta$-D-GlcNAc occupied at the upper and the lower domains

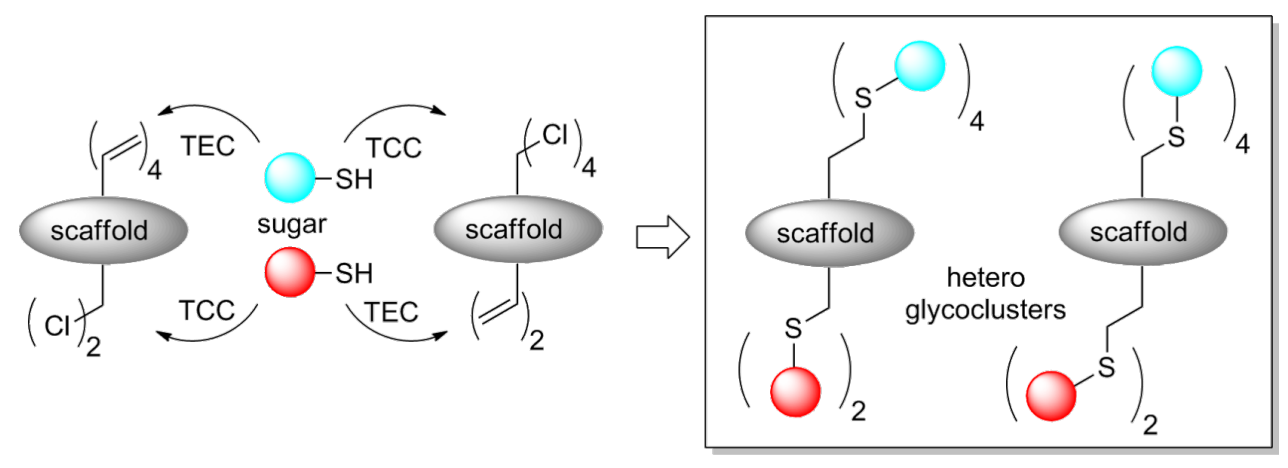

Figure 1: Chemical strategy for the construction of heteroglycoclusters. 


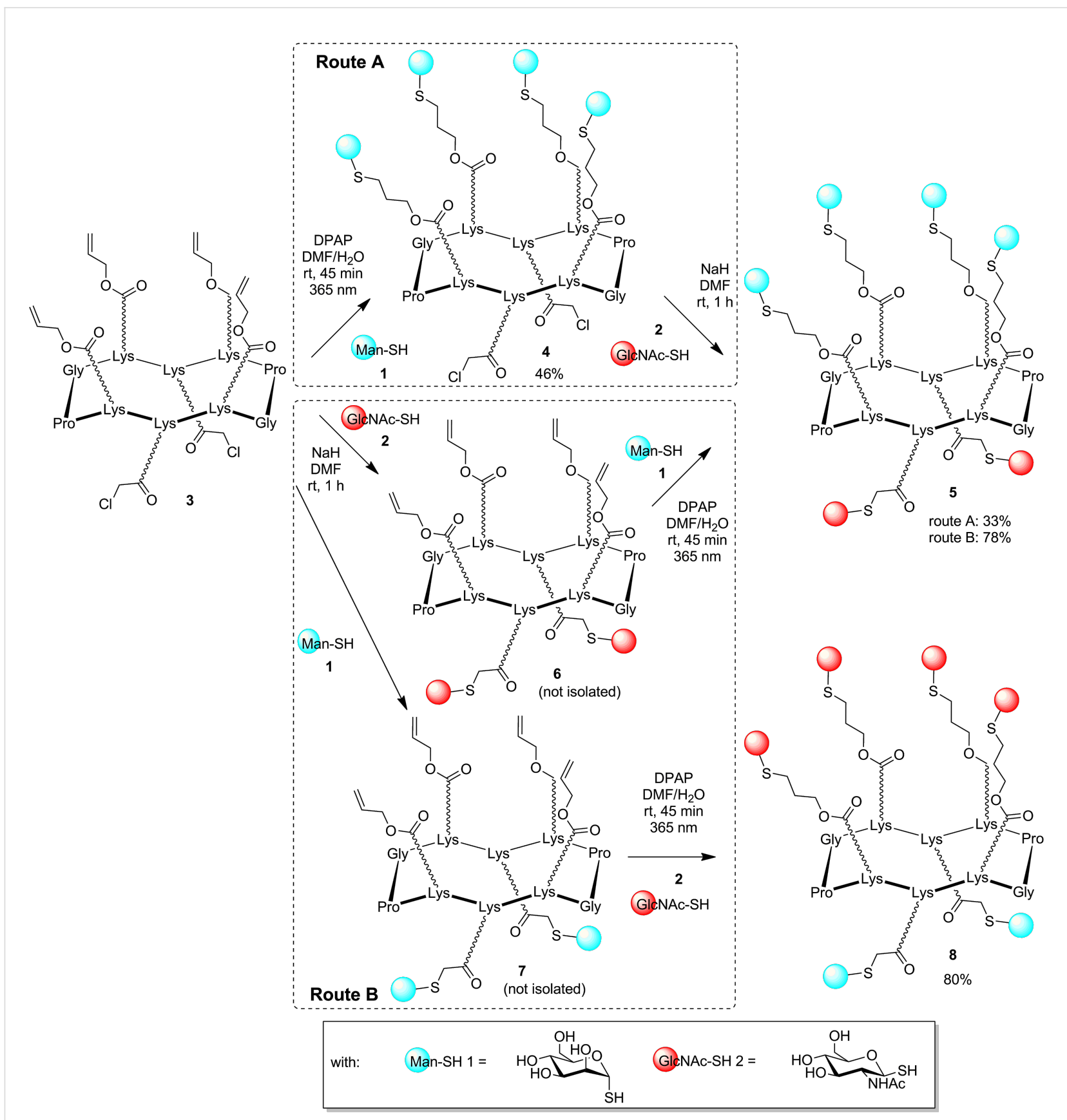

Scheme 1: Stepwise (Route A) and sequential one-pot (Route B) synthesis of hGCs.

of the scaffold, respectively, was obtained after 1 hour as confirmed by HPLC and MS analyses (Table 1).

We decided to investigate whether changing the reaction sequence could allow the one-pot assembly. We thus coupled $\beta$-D-GlcNAcSH 2 by TCC as the first step (Scheme 1, route B). Contrary to the previous route, we expected that the presence of unreacted sugar 2 (used in slight excess) might not interfere during the thiol-ene coupling as it should form disulfide adduct spontaneously. Therefore, the crude mixture was neutralized by addition of hydrochloric acid and compound $\mathbf{6}$ was used without further additional purification. $\alpha$-D-ManSH 1 was then conjugated by TEC and compound $\mathbf{5}$ was obtained in $78 \%$ after purification. Interestingly no side product corresponding to the addition of $\mathbf{2}$ on the Alloc group was detected. We concluded that performing reactions in this order (route B) makes the onepot assembly possible, faster and provides hGCs with higher yields (Table 1). 
Table 1: Analytical data of the hGCs

\begin{tabular}{|c|c|c|c|c|}
\hline compound & yield $(\%)^{a}$ & MS calc ${ }^{b}$ & MS found ${ }^{C}$ & $t_{\mathrm{R}}(\min )^{\mathrm{d}}$ \\
\hline 4 & 46 (6.9 mg) & 2351.9 & 2352.0 & 9.71 \\
\hline 5 (route A) & 33 (2.6 mg) & 2753.1 & 2753.2 & 8.24 \\
\hline 5 (route B) & 78 (13.8 mg) & 2753.1 & 2753.2 & 8.24 \\
\hline 8 & $80(10.2 \mathrm{mg})$ & 2835.8 & 2836.0 & 8.35 \\
\hline 11 & $77(13.1 \mathrm{mg})$ & 2666.1 & 2666.1 & 8.06 \\
\hline 13 & $54(14.4 \mathrm{mg})$ & 2747.1 & 2747.2 & 8.06 \\
\hline
\end{tabular}

aYields were calculated on isolated compounds after HPLC purification. ${ }^{\mathrm{b} C}$ Calculated mass for $[\mathrm{M}+\mathrm{H}]^{+}$. ${ }^{\mathrm{C}} \mathrm{MS}$ analysis was performed by electrospray ionization method in positive mode. ${ }^{\mathrm{d}} \mathrm{RP}-\mathrm{HPLC}$ retention time using a linear gradient $\mathrm{A}-\mathrm{B}, 95: 5$ to $0: 100 \mathrm{in} 20 \mathrm{~min}$, flow: $1.0 \mathrm{~mL} / \mathrm{min}, \lambda=214 \mathrm{~nm}$ and $250 \mathrm{~nm}$ (column: nucleosil 300-5 C18; solvent A: 0.09\% TFA in $\mathrm{H}_{2} \mathrm{O}$, solvent $\mathrm{B}: 0.09 \%$ TFA in $90 \%$ acetonitrile).

To verify the efficiency and versatility of this protocol, we decided to perform similar sequence of reactions with cyclopeptide 9 having reactive functionalities in reverse orientation compared to $\mathbf{3}$, i.e., four chloroacetyl and two Alloc moieties at the upper and the lower face, respectively (Scheme 2).

$\alpha$-D-ManSH was used for the TCC reaction and $\beta$-DGlcNAcSH for the subsequent TEC using a similar sequence of reactions described in Scheme 1. The HPLC profile of the crude mixture (Figure 2) showed that the successive TCC and TEC reactions give clean reaction mixtures to provide the hGC $\mathbf{1 1}$ with $77 \%$ yield.

The same strategy was followed to prepare compound $\mathbf{1 3}$ featuring two $\alpha$-D-Man and four $\beta$-D-GlcNAc. No difference of reactivity was observed whatever the scaffold or the glycosyl thiol used. All these products were obtained in good yield after

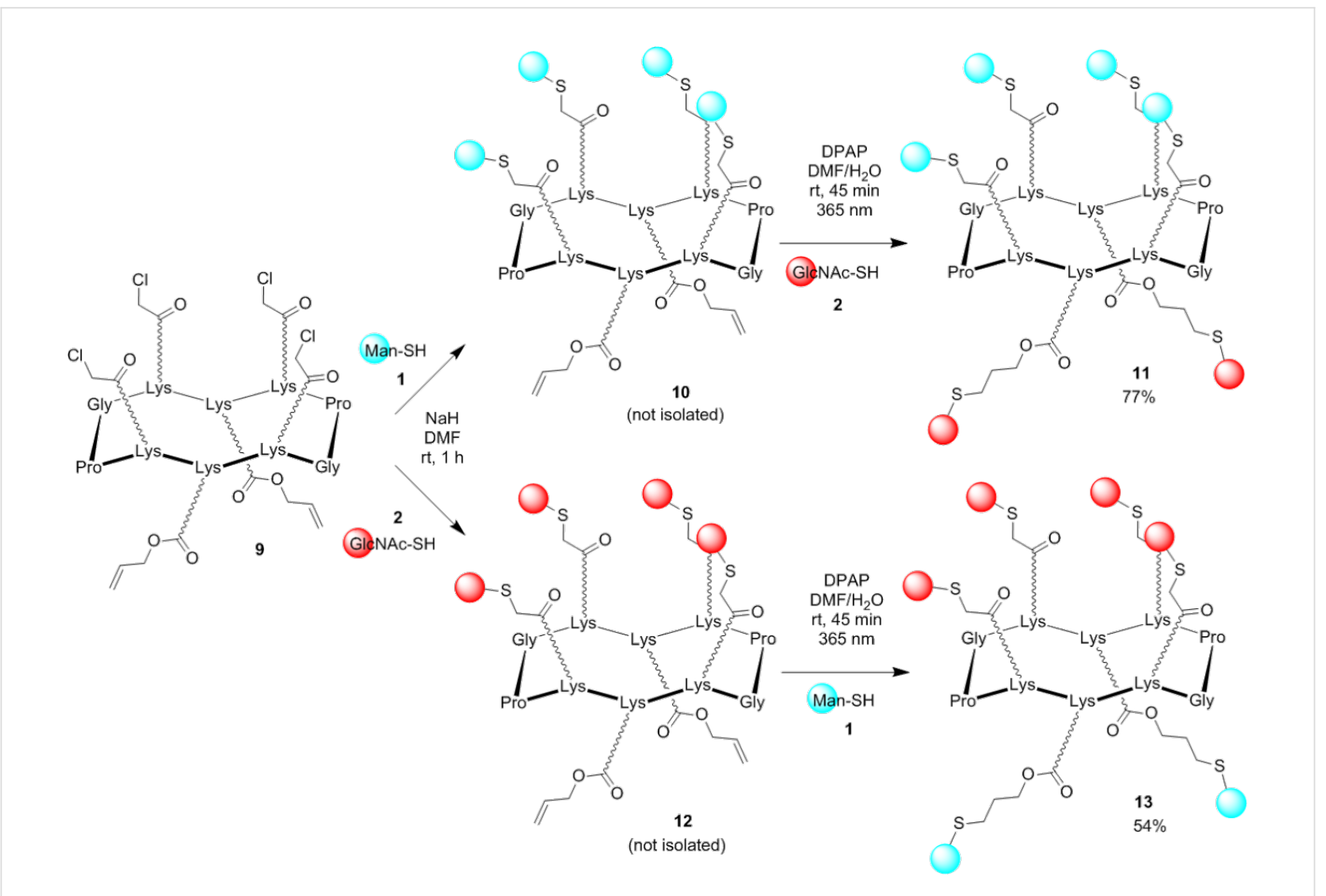




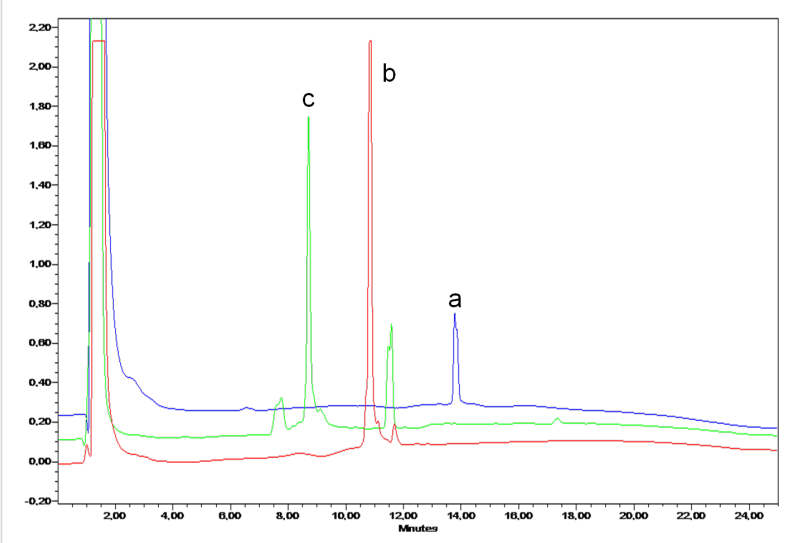

Figure 2: RP-HPLC profile of the one-pot synthesis of hGC 11 (linear A-B gradient: 5 to $100 \%$ B in $20 \mathrm{~min}, \lambda=214 \mathrm{~nm}$ ); (a, blue) cyclodecapeptide precursor 9 ; (b, red) crude mixture of intermediate product 10; (c, green) corresponds to crude mixture after TCC and TEC (11).

HPLC purification and gave the expected multicharged ions by electrospray mass spectrometry (Table 1).

\section{Conclusion}

In summary, we have developed the first synthesis of hGCs using a one-pot orthogonal chemoselective route by using dual thiol-chloroacetyl and thiol-ene couplings. The effectiveness of this method was demonstrated through the coupling of multiple copies of $\alpha$-D-ManSH and $\beta$-D-GlcNAcSH residues onto both addressable domains of cyclopeptide scaffolds displaying chloroacetyl and allyloxycarbonyl groups. While the first utilization of thiol-ene coupling in a stepwise approach requires an intermediate purification, a sequential one-pot assembly can be performed in good yields by starting with thiol-chloroacetyl coupling. This process is currently used in our laboratory for the construction of mutliantigenic synthetic vaccines against cancers.

\section{Experimental}

General details. All chemical reagents were purchased from Aldrich (Saint Quentin Fallavier, France) or Acros (Noisy-LeGrand, France) and were used without further purification. PyBOP was obtained from Calbiochem-Novabiochem (Merck Biosciences - VWR, Limonest, France). Analytical RP-HPLC was performed on a Waters system equipped with a Waters 600 controller and a Waters 2487 Dual Absorbance Detector. Analysis was carried out at $1.0 \mathrm{~mL} / \mathrm{min}$ (EC 125/3 nucleosil 300-5 C18) with UV monitoring at $214 \mathrm{~nm}$ and $250 \mathrm{~nm}$ using a linear A-B gradient (buffer A: $0.09 \% \mathrm{CF}_{3} \mathrm{CO}_{2} \mathrm{H}$ in water; buffer B: $0.09 \% \mathrm{CF}_{3} \mathrm{CO}_{2} \mathrm{H}$ in $90 \%$ acetonitrile). Preparative separation was carried out at $22 \mathrm{~mL} / \mathrm{min}$ (VP 250/21 nucleosil 300-7 C18) with UV monitoring at $214 \mathrm{~nm}$ and $250 \mathrm{~nm}$ using a linear A-B gradient (buffer A: $0.09 \% \mathrm{CF}_{3} \mathrm{CO}_{2} \mathrm{H}$ in water; buffer $\mathrm{B}$ : $0.09 \% \mathrm{CF}_{3} \mathrm{CO}_{2} \mathrm{H}$ in $90 \%$ acetonitrile). Mass spectrometry was performed using electrospray ionization on an Esquire 3000+ Bruker Daltonics in positive mode.

\section{General procedure for solid-phase peptide synthesis.} Assembly of all protected peptides was carried out on a synthesizer (Syro II, Biotage) using the Fmoc/t-Bu strategy and the Fmoc-Gly-Sasrin ${ }^{\mathrm{TM}}$ resin. Coupling reactions were performed using, relative to the resin loading, 3 equiv of Fmoc-protected amino acid activated in situ with 3 equiv of PyBOP and 6 equiv of DIPEA in DMF (10 mL/g resin) for $30 \mathrm{~min}$. Fmoc protecting groups were removed by treatment with a piperidine/DMF solution $1: 4(10 \mathrm{~mL} / \mathrm{g}$ resin) for $10 \mathrm{~min}$. Synthetic linear peptides were recovered directly upon acid cleavage (1\% TFA in $\mathrm{CH}_{2} \mathrm{Cl}_{2}$ ). The resins were treated for 3 min repeatedly until the resin beads became dark purple. The combined washings were concentrated under reduced pressure, and white solid peptides were obtained by precipitation from diethyl ether.

General procedure for peptide cyclization. All linear peptides were dissolved in $\mathrm{CH}_{2} \mathrm{Cl}_{2}(0.5 \mathrm{mM})$ and the $\mathrm{pH}$ was adjusted to 8 by addition of DIPEA. PyBOP (1.2 equiv) was added and the solution was stirred at room temperature for $1 \mathrm{~h}$. Evaporation of the solvent and precipitation in diethyl ether afforded the cyclic peptides as white solids.

General procedure for Boc deprotection. All cyclic peptides were dissolved in $\mathrm{CH}_{2} \mathrm{Cl}_{2}$ and then a solution at $40 \%$ of trifluoroacetic acid in $\mathrm{CH}_{2} \mathrm{Cl}_{2}$ with $2.5 \%$ of water as scavenger was added. The reaction was run until disappearance of stating material $(1 \mathrm{~h})$. Evaporation of the solvent and precipitation in diethyl ether afforded the cyclic peptides as white solids.

Cyclopeptide 3. To a solution of partial protected cyclopeptide [Lys(Aloc)-Lys-Lys(Aloc)-Pro-Gly-Lys(Aloc)-Lys-Lys(Aloc)Pro-Gly] (200 mg, $0.142 \mathrm{mmol})$ in dry DMF $(10 \mathrm{~mL})$ was added chloroacetic anhydride $(100 \mathrm{mg}, 0.304 \mathrm{mmol})$ and $\mathrm{pH}$ adjusted to 8 by adding $100 \mu \mathrm{L}$ of DIPEA. The brown solution was left stirring for $2 \mathrm{~h}$. The solvent was then evaporated, the brown residue was dissolved in a minimum amount of $\mathrm{CH}_{2} \mathrm{Cl}_{2}$ and then precipitated in $\mathrm{Et}_{2} \mathrm{O}$. The dark-yellow precipitate was purified by HPLC obtaining 3 (157 mg, 70\%) as white foam. Analytical RP-HPLC: $t_{\mathrm{R}}=16.64 \mathrm{~min}$ (gradient: 5 to $100 \% \mathrm{~B}$ in $20 \mathrm{~min}) ; \mathrm{ESIMS}^{+}(\mathrm{m} / \mathrm{z}):[\mathrm{M}+\mathrm{H}]^{+}$calcd for $\mathrm{C}_{70} \mathrm{Cl}_{2} \mathrm{H}_{111} \mathrm{~N}_{16} \mathrm{O}_{20}$, 1567.7; found, 1567.7 .

Homoglycocluster 4. Route A: Compounds 1 (14 mg, $0.076 \mathrm{mmol})$ and $3(10 \mathrm{mg}, 0.0064 \mathrm{mmol})$ were dissolved in dry DMF and DPAP $(2.0 \mathrm{mg}, 0.008 \mathrm{mmol})$ was added. The solution was irradiated at $365 \mathrm{~nm}$ for $45 \mathrm{~min}$. Compound 4 (6.9 mg, $46 \%$ ) was obtained as a white foam. Analytical RP-HPLC: $t_{\mathrm{R}}=$ 
$9.71 \mathrm{~min}$ (gradient: 5 to $100 \% \mathrm{~B}$ in $20 \mathrm{~min}) ; \mathrm{ESIMS}^{+}(\mathrm{m} / \mathrm{z})$ : [M $+\mathrm{H}]^{+}$calcd for $\mathrm{C}_{94} \mathrm{Cl}_{2} \mathrm{H}_{158} \mathrm{~N}_{16} \mathrm{O}_{40} \mathrm{~S}_{4}, 2351.9$; found, 2352.0.

Heteroglycocluster 5. Route A: Compounds 4 (6.9 mg, $0.029 \mathrm{mmol})$ and $2(1.7 \mathrm{mg}, 0.0696 \mathrm{mmol})$ were dissolved in dry DMF $(300 \mu \mathrm{L})$ and $\mathrm{NaH}(0.28 \mathrm{mg}, 0.0696 \mathrm{mmol})$ was added. The heterogeneous solution was left stirring $2 \mathrm{~h}$ at $\mathrm{rt}$. The crude mixture was then purified at HPLC obtaining 5 $(2.6 \mathrm{mg}, 33 \%)$ as a white foam. Analytical RP-HPLC: $t_{\mathrm{R}}=$ 8.24 min (gradient: 5 to $100 \%$ B in $20 \mathrm{~min}$ ); $\operatorname{ESIMS}^{+}(\mathrm{m} / \mathrm{z})$ : [M $+\mathrm{H}]^{+}$calcd for $\mathrm{C}_{110} \mathrm{H}_{187} \mathrm{~N}_{18} \mathrm{O}_{60} \mathrm{~S}_{6}, 2753.1$; found, 2753.2.

Heteroglycocluster 5. Route B (one-pot assembly). Compounds $2(3.6 \mathrm{mg}, 0.015 \mathrm{mmol})$ and $3(10 \mathrm{mg}, 0.0064 \mathrm{mmol})$ were dissolved in dry DMF $(300 \mu \mathrm{L})$ and $\mathrm{NaH}(0.5 \mathrm{mg}$, $0.015 \mathrm{mmol}$ ) was added. After stirring $1 \mathrm{~h}$ at room temperature, analytical HPLC indicated complete disappearance of $\mathbf{3}$ and the appearance of a new product corresponding to compound $\mathbf{6}$. Analytical HPLC: $t_{\mathrm{R}}=11.34$ (gradient: 5 to $100 \% \mathrm{~B}$ in $20 \mathrm{~min}$ ); ESIMS $^{+}(m / z):[\mathrm{M}+\mathrm{H}]^{+}$calcd for $\mathrm{C}_{86} \mathrm{H}_{139} \mathrm{~N}_{18} \mathrm{O}_{30} \mathrm{~S}_{2}, 1968.0$; found, 1969.3. The crude mixture was treated with $1 \% \mathrm{HCl}$ aqueous solution $(150 \mu \mathrm{L})$ then compound 1 (14.52 mg, $0.0768 \mathrm{mmol}$ ) and DPAP (1.96 $\mathrm{mg}, 0.0077 \mathrm{mmol})$ were added. The solution was irradiated at $365 \mathrm{~nm}$ for $45 \mathrm{~min}$. Heteroglycocluster 5 was obtained as a white foam after HPLC purification. Yield: 78\%; $(13.8 \mathrm{mg})$; analytical HPLC: $t_{\mathrm{R}}=8.24 \mathrm{~min}$ (gradient: 5 to $100 \% \mathrm{~B}$ in $20 \mathrm{~min}$ ); $\operatorname{ESIMS}^{+}(\mathrm{m} / \mathrm{z}):[\mathrm{M}+\mathrm{H}]^{+}$ calcd for $\mathrm{C}_{110} \mathrm{H}_{187} \mathrm{~N}_{18} \mathrm{O}_{60} \mathrm{~S}_{6}, 2753.1$; found, 2753.2.

Heteroglycocluster 8. Heteroglycocluster $\mathbf{8}$ wad obtained from 1 (2.4 mg, $0.0122 \mathrm{mmol}), 3$ (8 $\mathrm{mg}, 0.0051 \mathrm{mmol})$ and 2 (14.2 $\mathrm{mg}, 0.06 \mathrm{mmol})$ as described for 5 . Yield: $80 \%(10.2 \mathrm{mg})$; analytical RP-HPLC: $t_{\mathrm{R}}=8.35 \mathrm{~min}$ (gradient: 5 to $100 \% \mathrm{~B}$ in $20 \mathrm{~min})$; ESIMS $^{+}(\mathrm{m} / \mathrm{z}):[\mathrm{M}+\mathrm{H}]^{+}$calcd for $\mathrm{C}_{114} \mathrm{H}_{193} \mathrm{~N}_{20} \mathrm{O}_{50} \mathrm{~S}_{6}$, 2835.8; found, 2836.0 .

Cyclopeptide 9. To a solution of the partial protected cyclopeptide [Lys-Lys(Aloc)-Lys-Pro-Gly-Lys-Lys(Aloc)-Lys-ProGly] $(871 \mathrm{mg}, 0.70 \mathrm{mmol})$ in dry DMF $(40 \mathrm{~mL})$ was added chloroacetic anhydride $(601.2 \mathrm{mg}, 3.36 \mathrm{mmol})$ and the $\mathrm{pH}$ was adjusted to 8 by adding $250 \mu \mathrm{L}$ of DIPEA. The brown solution was left stirring for $4 \mathrm{~h}$. Solvent was then evaporated; the brown residue was dissolved in a minimum amount of $\mathrm{CH}_{2} \mathrm{Cl}_{2}$ and then precipitated in $\mathrm{Et}_{2} \mathrm{O}$. The dark-brown precipitate was purified by HPLC obtaining 9 (459 mg, 42\%) as white foam. Analytical RP-HPLC: $t_{\mathrm{R}}=12.67 \mathrm{~min}$ (gradient: 5 to $100 \% \mathrm{~B}$ in $20 \mathrm{~min})$; $\operatorname{ESIMS}^{+}(\mathrm{m} / \mathrm{z})$ : $[\mathrm{M}+\mathrm{H}]^{+}$calcd for $\mathrm{C}_{66} \mathrm{Cl}_{4} \mathrm{H}_{105} \mathrm{~N}_{16} \mathrm{O}_{18}$, 1582.7; found, 1582.0 .

Heteroglycocluster 11. Heteroglycocluster 11 was obtained from 9 (13 $\mathrm{mg}, 0.0084 \mathrm{mmol}), \mathbf{1}(8 \mathrm{mg}, 0.0402 \mathrm{mmol})$ and $\mathbf{2}$
(11.9 $\mathrm{mg}, 0.0504 \mathrm{mmol}$ ) as described for 5. Yield: $77 \%$ $\left(13.1 \mathrm{mg}\right.$ ); analytical RP-HPLC: $t_{\mathrm{R}}=8.06 \mathrm{~min}$ (gradient: 5 to $100 \% \mathrm{~B}$ in $20 \mathrm{~min}) ; \mathrm{ESIMS}^{+}(\mathrm{m} / \mathrm{z}):[\mathrm{M}+\mathrm{H}]^{+}$calcd for $\mathrm{C}_{106} \mathrm{H}_{180} \mathrm{~N}_{18} \mathrm{O}_{48} \mathrm{~S}_{6}$, 2666.1; found, 2666.1.

Heteroglycocluster 13. Heteroglycocluster 13 was obtained from 9 (15 mg, $0.0097 \mathrm{mmol}$ ), 2 (11.0 $\mathrm{mg}, 0.0466 \mathrm{mmol}$ ) and $\mathbf{1}$ (11.4 mg, $0.058 \mathrm{mmol}$ ) as described for 5. Yield: $54 \%$ $\left(14.4 \mathrm{mg}\right.$ ); analytical RP-HPLC: $t_{\mathrm{R}}=8.06 \mathrm{~min}$ (gradient: 5 to $100 \% \mathrm{~B}$ in $20 \mathrm{~min})$; $\mathrm{ESIMS}^{+}(\mathrm{m} / \mathrm{z}):[\mathrm{M}+\mathrm{H}]^{+}$calcd for $\mathrm{C}_{110} \mathrm{H}_{184} \mathrm{~N}_{20} \mathrm{O}_{48} \mathrm{~S}_{6}, 2747.1$; found, 2747.2.

\section{Supporting Information}

\section{Supporting Information File 1}

HPLC chromatograms and mass spectra of all compounds.

[http://www.beilstein-journals.org/bjoc/content/

supplementary/1860-5397-10-160-S1.pdf]

\section{Acknowledgments}

This work was supported by the "Communauté d'agglomération Grenoble-Alpes Métropole" (Nanobio program), the "Cluster de Recherche Chimie de la Région Rhône-Alpes" (BT), the Ligue contre le cancer (MF), the Agence Nationale de la Recherche Grant ANR-12-JS07-0001-01 "VacSyn" (GCD), the COST action CM1102 and the Labex ARCANE (ANR-11-LABX0003-01).

\section{References}

1. Varki, A.; Cummings, R. D.; Esko, J. D.; Freeze, H. H.; Stanley, P.; Bertozzi, C. R.; Hart, G. W.; Etzler, M. E. Essentials of Glycobiology, 2nd ed.; Cold Spring Harbour: New York, 2009.

2. Kiessling, L. L.; Gestwicki, J. E.; Strong, L. E. Angew. Chem., Int. Ed. 2006, 45, 2348. doi:10.1002/anie.200502794

3. Chabre, Y. M.; Roy, R. Adv. Carbohydr. Chem. Biochem. 2010, 63, 165. doi:10.1016/S0065-2318(10)63006-5

4. Renaudet, O.; Roy, R. Chem. Soc. Rev. 2013, 42, 4515. doi:10.1039/C3CS90029K

5. Jiménez Blanco, J. L.; Ortiz Mellet, C.; Garcia Fernández, J. M. Chem. Soc. Rev. 2013, 42, 4518. doi:10.1039/c2cs35219b

6. Patel, A.; Lindhorst, T. K. Eur. J. Org. Chem. 2002, 79. doi:10.1002/1099-0690(20021)2002:1<79::AID-EJOC79>3.0.CO;2-1

7. Ortega-Muñoz, M.; Perez-Balderas, F.; Morales-Sanfrutos, J.; Hernandez-Mateo, F.; Isac-García, J.; Santoyo-Gonzalez, F. Eur. J. Org. Chem. 2009, 2454. doi:10.1002/ejoc.200801169

8. Katajisto, J.; Karskela, T.; Heinonen, P.; Lönnberg, H. J. Org. Chem. 2002, 67, 7995. doi:10.1021/jo026053b

9. Lindhorst, T. K.; Bruegge, K.; Fuchs, A.; Sperling, O. Beilstein J. Org. Chem. 2010, 6, 801. doi:10.3762/bjoc.6.90

10. Keding, S. J.; Danishefsky, S. J. Proc. Natl. Acad. Sci. U. S. A. 2004, 101, 11937. doi:10.1073/pnas.0401894101

11. Deguise, I.; Lagnoux, D.; Roy, R. New J. Chem. 2007, 31, 1321. doi:10.1039/b701237c 
12. Wolfenden, M. L.; Cloninger, M. J. Bioconjugate Chem. 2006, 17, 958. doi:10.1021/bc060107x

13. Gómez-García, M.; Benito, J. M.; Rodríguez-Lucena, D.; Yu, J.-X.; Chmurski, K.; Ortiz Mellet, C.; Gutiérrez Gallego, R.; Maestre, A.; Defaye, J.; Garcìa Fernàndez, J. M. J. Am. Chem. Soc. 2005, 127, 7970. doi:10.1021/ja050934t

14. Gómez-García, M.; Benito, J. M.; Gutiérrez-Gallego, R.; Maestre, A.; Ortiz Mellet, C.; García Fernández, J. M.; Jiménez Blanco, J. L. Org. Biomol. Chem. 2010, 8, 1849. doi:10.1039/b920048g

15. Gómez-Garcia, M.; Benito, J. M.; Butera, A. P.; Ortiz-Mellet, C.; Garcia Fernàndez, J. M.; Jiménez Blanco, J. L. J. Org. Chem. 2012, 77, 1273. doi:10.1021/jo201797b

16. Geng, J.; Mantovani, G.; Tao, L.; Nicolas, J.; Chen, G.; Wallis, R.; Mitchell, D. A.; Johnson, B. R. G.; Evans, S. D.; Haddleton, D. M. J. Am. Chem. Soc. 2007, 129, 15156. doi:10.1021/ja072999x

17. Dondoni, A. Angew. Chem., Int. Ed. 2008, 47, 8995. doi:10.1002/anie.200802516

18. Rostovtsev, V. V.; Green, L. G.; Fokin, V. V.; Sharpless, K. B. Angew. Chem., Int. Ed. 2002, 41, 2596. doi:10.1002/1521-3773(20020715)41:14<2596::AID-ANIE2596>3.0.CO $; 2-4$

19. Elsner, K.; Boysen, M. M. K.; Lindhorst, T. K. Carbohydr. Res. 2007, 342, 1715. doi:10.1016/j.carres.2007.05.005

20. Thomas, B.; Fiore, M.; Bossu, I.; Dumy, P.; Renaudet, O. Beilstein J. Org. Chem. 2012, 8, 421. doi:10.3762/bjoc.8.47

21. Fiore, M.; Chambery, A.; Marra, A.; Dondoni, A. Org. Biomol. Chem. 2009, 7, 3910. doi:10.1039/b912686d

22. Kottari, N.; Chabre, Y. M.; Shiao, T. C.; Roy, R. Chem. Commun. 2014, 50, 1983. doi:10.1039/C3CC46633G

23. MacDougall, J. M.; Zhang, X.-D.; Polgar, W. E.; Kharoyan, T. V.; Toll, L.; Cashman, J. R. J. Med. Chem. 2004, 47, 5809. doi:10.1021/jm049554t

24. Bernardes, G. J. L.; Gamblin, D. P.; Davis, B. G. Angew. Chem., Int. Ed. 2006, 45, 4007. doi:10.1002/anie.200600685

25. Gingras, M.; Chabre, Y. M.; Roy, M.; Roy, R. Chem. Soc. Rev. 2013, 42, 4823. doi:10.1039/c3cs60090d

26. Fiore, M.; Berthet, N.; Marra, A.; Gillon, E.; Dumy, P.; Dondoni, A.; Imberty, A.; Renaudet, O. Org. Biomol. Chem. 2013, 11, 7113. doi:10.1039/c3ob41203b

27. Eggimann, G. A.; Buschor, S.; Darbre, T.; Reymond, J.-L. Org. Biomol. Chem. 2013, 11, 6717. doi:10.1039/C3OB41023D

\section{License and Terms}

This is an Open Access article under the terms of the Creative Commons Attribution License

(http://creativecommons.org/licenses/by/2.0), which permits unrestricted use, distribution, and reproduction in any medium, provided the original work is properly cited.

The license is subject to the Beilstein Journal of Organic Chemistry terms and conditions:

(http://www.beilstein-journals.org/bjoc)

The definitive version of this article is the electronic one which can be found at:

doi:10.3762/bjoc. 10.160 